Original Research Article

\title{
Correlation of serological markers with haematological parameters in early diagnosis of dengue infection in dengue prone areas
}

\author{
Kambale T.J. ${ }^{1}$, Sawaimul K.D. ${ }^{2}$, Iqbal M.B. ${ }^{3}$, Bardapurkar P. ${ }^{4}$, Kumar H. ${ }^{5}$, Baravkar A. ${ }^{6}$ \\ ${ }^{1}$ Dr.Tushar Jalindar Kambale, Associate Professor, ${ }^{2}$ Dr. Komal D Sawaimul, Assistant Professor, ${ }^{3}$ Dr. M. Banyameen \\ Iqbal, Associate Professor, ${ }^{4}$ Dr. Padmakar Bardapurkar, Resident Doctor, ${ }^{5}$ Dr. Harsh Kumar, HOD \& Professor, \\ ${ }^{6}$ Dr. Abhishek Baravkar, Assistant Professor, all authors are affiliated with Department of Pathology, Dr. DY Patil \\ Medical Collage and Research Center, Dr. DY Patil University, Pimpri, Pune, Maharashtra, India.
}

Corresponding Author: Dr. Komal D Sawaimul, Assistant Professor, Department of Pathology, Dr. D Y Patil Medical Collage and Research Center, Dr. DY Patil University, Sant Tukaram Nagar, Pimpri, Pune. Email: drkomal15@gmail.com

\begin{abstract}
Background: Dengue is a serious, rapidly spreading tropical mosquito-borne viral disease caused by dengue virus belonging to the family flaviviridae and genus flavivirus in the last five decades. In many dengue endemic remote areas with limited laboratory diagnostic services their rapid diagnostic tests are simple method which provides the immediate diagnosis and early management. Materials and methods: The study includes clinically suspected 1236 cases with all haematological parameters and tested at clinical laboratory in which 500 serum samples showed positivity for one or more markers like NS1, IgM or IgG antibodies. Results: In our study among 500 seropositive cases thrombocytopenia ( $<1$ lakh) was evident in $66.7 \%$ and in 736 seronegative cases thrombocytopenia was seen in $27.47 \%$. Out of 323 NS1 positive cases, thrombocytopenia was evident in $56.0 \%$ and in exclusive antibody positive cases thrombocytopenia was noted in 19.2\%. These associations were considered to be statistically significant. Conclusion: The problem of dengue is complex in India because large population, poor medical and diagnostic facilities and inadequate mosquito control. Therefore, studies like this will significantly contribute to the early diagnosis, management and can reduce patient's morbidity and mortality.
\end{abstract}

Keywords: Dengue Virus, Rapid diagnostic test, Thrombocytopenia

\section{Introduction}

Dengue is a mosquito-borne viral disease caused by dengue virus belonging to the family flaviviridae and genus flavivirus. It is one of the most serious, rapidly spreading tropical diseases in the last five decades. The incidence has increased many folds with increasing geographic expansion from urban to rural population. Approximately 2.5 billion people live in dengue endemic countries with an estimated 50 million dengue infections at risk annually [1,2,3].

Dengue virus is small single-stranded RNA virus which is spherical in shape having $50 \mathrm{~nm}$ in diameter. It contains a host-derived membrane bilayer, a single copy of a positive-sense, single-stranded RNA genome and multiple copies of the three structural proteins and seven non-structural proteins [NS]. Dengue virus is

Manuscript received: $10^{\text {th }}$ January 2018

Reviewed: $20^{\text {th }}$ January 2018

Author Corrected: $30^{\text {th }}$ January 2018

Accepted for Publication: $7^{\text {th }}$ February 2018 divided in five types due to its characteristic antigenicity as DEN-1 to DEN-5. Out of these DEN-2 and DEN-3 known as "Asian" genotypes which are frequently associated with severe disease accompanying secondary dengue infections [4-8].

Now the diagnosis and confirmation of dengue viral infection can be done by viral culture, viral RNA detection by reverse transcriptase Polymerase Chain Reaction (RTPCR) and serological tests such as an immunoglobulin M (IgM) capture enzyme-linked immunosorbent assay (MAC-ELISA) [9].

In many dengue endemic remote areas with limited laboratory diagnostic services there rapid diagnostic tests are simple method which provides the immediate diagnosis and early management. The confirmation of these results can be done later as there is no antiviral treatment or vaccine available to prevent infection. But 


\section{Original Research Article}

careful fluid management and monitoring for complications is the only option available. As a result of early fluid management regimes and interventions, the case mortality rates can be decreased in many dengue endemic areas [10].

\section{Materials and Methods}

The present study was a retrospective study, conducted in the Pathology department of Dr. D. Y. Patil hospital at Pune from January 2016 to November 2016. Total 1236 serum samples were collected from clinically suspected cases of dengue out of which 500 samples were positive for either one or more of the dengue parameters. The samples were tested immediately in central laboratory for NS1 antigen, IgM and $\operatorname{IgG}$ antibodies by using the immunochromatography test kit- Dengue NS1 antigen and antibody using Combi Card supplied by well-known manufacturer.

The tests were performed in accordance with the manufacturer's instructions. Haematological parameters of all the dengue positive cases were recorded using haematology analyser. Statistical analysis was done by using Chi-square and Z-test wherever applicable.

\section{Results}

Table No.-1: Distribution of Dengue serological markers for Dengue infection [n=500]

\begin{tabular}{|c|c|c|c|c|}
\hline Dengue specific parameters & Male & Female & Total positive serum samples & Percentage \\
\hline NS1 only & 179 & 117 & 296 & $59.2 \%$ \\
\hline IgM only & 16 & 5 & 21 & $4.2 \%$ \\
\hline IgG only & 87 & 64 & 151 & $30.2 \%$ \\
\hline NS1 + IgM only & 10 & 4 & 14 & $2.8 \%$ \\
\hline NS1 + IgG only & 7 & 4 & 11 & $2.2 \%$ \\
\hline NS1 + IgM + IgG & 1 & 1 & 2 & $0.4 \%$ \\
\hline IgM + IgG & 3 & 2 & 5 & $1 \%$ \\
\hline Total & $\mathbf{3 0 3}$ & $\mathbf{1 9 7}$ & $\mathbf{5 0 0}$ & $\mathbf{1 0 0} \%$ \\
\hline
\end{tabular}

The clinically suspected 1236 cases are tested at clinical laboratory in which 500 serum samples showed positivity for one or more markers like NS1, IgM or IgG out of which 303 are male and 197 were female. The majority of 296 (59.2\%) cases were positive for only NS1 antigen, followed by IgG and IgM with $151(30.2 \%)$ and 21 (4.2\%) cases respectively [Table 1].

Table No.-2: Comparison of platelet count with various dengue parameters $(n=500)$

\begin{tabular}{|c|c|c|c|c|c|}
\hline \multirow{3}{*}{$\begin{array}{c}\text { Dengue specific } \\
\text { Parameters }\end{array}$} & \multirow{3}{*}{$\begin{array}{c}\text { Total } \\
\text { positive } \\
\text { serum } \\
\text { samples }\end{array}$} & \multicolumn{4}{|c|}{ Platelet counts } \\
\hline & & \multicolumn{3}{|c|}{ Thrombocytopenia $n=345$ [69\%] } & \multirow{2}{*}{$\begin{array}{c}\text { Normal } n=155[31 \%] \\
>1.5 \text { lakh/cumm }\end{array}$} \\
\hline & & $<50,000 /$ cumm) & $\begin{array}{c}50000 \text { - } 1 \\
\text { lakh/cumm }\end{array}$ & $\begin{array}{l}1 \text { lakh - } 1.5 \\
\text { lakh /cumm }\end{array}$ & \\
\hline NS1 only & 296 & 44 & 123 & 94 & 35 \\
\hline IgM only & 21 & 3 & 5 & 8 & 5 \\
\hline IgG only & 151 & 6 & 18 & 20 & 107 \\
\hline NS1 + IgM only & 14 & 3 & 7 & 3 & 1 \\
\hline NS1 + IgG only & 11 & 0 & 2 & 4 & 5 \\
\hline $\mathrm{NS} 1+\mathrm{IgM}+\mathrm{IgG}$ & 2 & 0 & 2 & 0 & 0 \\
\hline $\operatorname{IgM}+\operatorname{IgG}$ & 5 & 0 & 2 & 1 & 2 \\
\hline Total & 500 & 56 & 159 & 130 & 155 \\
\hline
\end{tabular}

All the suspected cases were screened for platelet count, WBC count and heamoglobin. Out of 500 seropositive cases 345 $(69 \%)$ were showing thrombocytopenia $(<1.5$ lakh) while $155(31 \%)$ cases are showing normal platelet count [Table 2]. 


\section{Original Research Article}

Table No.-3: Comparison of haemoglobin with various dengue parameters $(\mathbf{n}=\mathbf{5 0 0})$

\begin{tabular}{|c|c|c|c|c|}
\hline \multirow{2}{*}{$\begin{array}{c}\text { Dengue specific } \\
\text { Parameters }\end{array}$} & Total positive & \multicolumn{3}{|c|}{ Haemoglobin } \\
\cline { 3 - 5 } & serum samples & $<\mathbf{7 . 0 g m \%}$ & $<\mathbf{1 ~ t o 9 . 9 ~ g m \% ~}$ & $>\mathbf{1 0 . 0 g m \%}$ \\
\hline NS1 only & 296 & 1 & 6 & 289 \\
\hline IgM only & 21 & 0 & 0 & 21 \\
\hline IgG only & 151 & 1 & 4 & 146 \\
\hline NS1 + IgM only & 14 & 0 & 0 & 11 \\
\hline NS1 + IgG only & 11 & 0 & 0 & 2 \\
\hline NS1 + IgM + IgG & 2 & 0 & 0 & 4 \\
\hline IgM + IgG & 5 & 1 & $\mathbf{1 0}$ & $\mathbf{4 8 7}$ \\
\hline Total & $\mathbf{5 0 0}$ & $\mathbf{3}$ & 0 & 14 \\
\hline
\end{tabular}

Out of 500 cases study showed $487(97.4 \%)$ cases with haemoglobin values more than $10 \mathrm{gm} \%$. Only 3 cases and 10 cases show haemoglobin range $<7.0 \mathrm{gm} \%$ and between $7.1-9.9 \mathrm{gm} \%$ respectively. [Table 3]

Table No.-4: Comparison of Total leukocyte count with various dengue parameters $(\mathbf{n}=500)$

\begin{tabular}{|c|c|c|c|c|}
\hline $\begin{array}{c}\text { Dengue specific } \\
\text { Parameters }\end{array}$ & $\begin{array}{c}\text { Total positive } \\
\text { serum samples }\end{array}$ & \multicolumn{3}{|c|}{ Total leukocyte count } \\
\cline { 3 - 5 } & & $\mathbf{4 , 0 0 0 / c m m}$ & $\mathbf{4 , 0 0 0 - 1 1 , 0 0 0 / c m m ~}$ & >11,000/cmm \\
\hline NS1 only & 296 & 113 & 172 & 11 \\
\hline IgM only & 21 & 6 & 14 & 18 \\
\hline IgG only & 151 & 15 & 9 & 1 \\
\hline NS1 + IgM only & 14 & 4 & 5 & 4 \\
\hline NS1 + IgG only & 11 & 2 & 2 & 0 \\
\hline NS1 + IgM + IgG & 2 & 0 & 4 & 35 \\
\hline IgM + IgG & 5 & 1 & 324 & 0 \\
\hline Total & 500 & 141 & 118 & 1 \\
\hline
\end{tabular}

Study also showed 141 (28.2\%) cases of leukopenia and 35 (7\%) cases of leucocytosis. [Table no.4]

Table No.-5: Association of platelet counts with seropositivity in dengue infection

\begin{tabular}{|c|c|c|c|}
\hline Platelet Count & $\begin{array}{c}\text { Count Dengue Positive } \\
\text { Cases }\end{array}$ & Dengue Negative Cases & Total \\
\hline$<1,00,000 / \mathrm{ml}$ & $215[43.0 \%]$ & $187[25.4 \%]$ & 402 \\
\hline$>1,00,000 / \mathrm{ml}$ & $285[57.0 \%]$ & $549[74.6 \%]$ & $\mathbf{1 2 3 6}$ \\
\hline Total & $\mathbf{5 0 0}[\mathbf{1 0 0} \%]$ & $\mathbf{7 3 6}[\mathbf{1 0 0} \%]$ & 834 \\
\hline \multicolumn{2}{|r|}{ The P value is less than 0.0001. The association is considered to be statistically significant. } \\
\hline
\end{tabular}

Table No. 6 Association of platelet counts with NS1 positivity in dengue infection

\begin{tabular}{|c|c|c|c|}
\hline \multicolumn{4}{|c|}{ Table No. 6 Association of platelet counts with NS1 positivity in dengue infection } \\
\hline Platelet Count & $<1,00,000 / \mathrm{ml}$ & $<1,00,000 / \mathrm{ml}$ & Total \\
\hline NS1 Positive & 181 & 142 & 177 \\
\hline NS1 antigen negative & 34 & $\mathbf{2 8 5}$ & $\mathbf{5 0 0}$ \\
\hline Total & $\mathbf{2 1 5}$ & \multicolumn{2}{|c|}{} \\
\hline \multicolumn{2}{|c|}{ The P value is less than 0.0001. The association is considered to be statistically significant. } \\
\hline
\end{tabular}




\section{Original Research Article}

\section{Discussion}

In our study $323 / 500(64.6 \%)$ cases are positive for NS1 antigen which are comparable to the study of Tathe $\mathrm{S}$ et al in which 56/93 (60\%) were positive [11] Badave et al have shown $54 / / 126(42.9 \%)$ cases to be positive for NS1 [12]. Other studies by Kulkarni et al have shown NS1 positivity in 95/320 (30\%) cases [13]. Datta and Shrivastava have shown that NS1 was positive in $140 / 600(23.3 \%)$ and $15 / 91(16 \%)$ cases respectively $[14,15]$.

From 500 positive cases, $21(4.2 \%)$ are positive for IgM only. This finding is comparable with studies of Badave et al and Sindhanai et al in which $6(4.7 \%)$ and $9(9.7 \%)$ were positive while as Tathe $\mathrm{S}$ et al reported it to be 16 $(68.75 \%)$. Our study shows $151(30.2 \%)$ cases to be positive for IgG only which is comparable to the study done by Badave et al and Sindhanai V et al. [11, 12, 16]

In Primary dengue case there will be a low titre and slow rising of antibodies. IgM antibody will appear first after 3-5 day followed by IgG antibody at the end of first week of illness. IgM levels peak about two weeks after the onset of symptoms and then decline generally to undetectable levels over 2-3 months. But anti-dengue serum $\operatorname{IgG}$ is increasing slowly after first week and there after it remains detectable after several months, and probably even for life. In contrast during secondary infection, rapid increase and high titre of antibodies are seen, i.e., high levels of $\operatorname{IgG}$ can be detected even during acute phase of secondary infection and IgM response is variable $[1,17]$.

In our study, primary infection [positive for NS1 Ag, IgM, NS1 + IgM] was seen in 333 [66.7\%] cases and secondary infection [positive for IgG, NS1 + IgG, IgM $+\mathrm{IgG}, \mathrm{NS} 1+\mathrm{IgM}+\mathrm{IgG}]$ was seen in 137 cases [33.3\%]. (Table 1). Other studies by Golia et al. reported $57.4 \%$ primary dengue infections and $42.6 \%$ secondary dengue infections. Sindhanai V et al study showed primary infection in $59 \%$ cases and secondary dengue infections in $41 \%[16,18]$.

In Dengue fever the virus may interact and activate platelets leading to thrombocytopenia or may affect growth and differentiation of thrombopoiet in induced megakaryopoiesis inducing apoptotic cell changes in a subpopulation of early megakaryocytic progenitors. These events might contribute towards the origin of thrombocytopenia in dengue disease. In our study among 500 seropositive cases thrombocytopenia $(<1$ lakh) was evident in $215(66.7 \%)$ which is comparable to $68.8 \%$ in the study of Kulkarni et al and $81.1 \%$ in the study of Tathe et al Study. Out of 736 seronegative cases thrombocytopenia was seen in 187 (27.47\%) and this association is considered to be statistically significant [Table no. 5]. This Reduction in platelet count observed in dengue negative cases may be due to other causes like viral infections other than dengue, vitamin deficiency, collagen vascular disorders, drug induced thrombocytopenia etc [19,20]. Out of 323 NS1 positive cases, thrombocytopenia was evident in $181(56.0 \%)$ and in exclusive antibody positive cases, thrombocytopenia was noted in $34(19.2 \%)$ [Table No.6]. This association is considered to be statistically significant which is comparable to the study of Kulkarni et al, Sindhanai et al and Tathe et al Study.[11,13,16]

The cases with rapid decrease in platelet and white blood cell count with rising haematocrit levels are most likely to be due to dengue infection [1]. In our study out of 500 positive cases of dengue infection; leucopenia was evident in $141(28.2 \%)$ cases and leucocytosis in 35 (7\%) cases [Table No.6]. While the study done by Manimala S there were $57(57 \%)$ cases of leucopenia which is not comparable with our study. This disparity in results may be due to difference in sample size [21].

\section{Conclusion and future}

In this country the problem of dengue is complex due to the large population, poor medical and diagnostic facilities and inadequate mosquito control. This country needs a quick effective technique and reliable diagnosis in addressing this potentially fatal, epidemic prone infection and large number of virus laboratories to confirm it and alert the public to take action. Therefore, studies like this will significantly contribute to the clinical management and can reduce patient's morbidity and mortality. To conclude this study emphasises on the fact that dengue is a life-threatening condition and there is a need for early diagnosis and treatment in order to prevent its complications.

\section{Author contribution}

Author No. 1: Data compilation, processing and writing of manuscript.

Author No. 2: corresponding and statistical analysis

Author No. 3: final proof reading

Author No. 4: data collection, typing and formatting

Author No. 5: overall supervision and guidance

Author No. 6: typing and formatting 


\section{Original Research Article}

Funding: Nil, Conflict of interest: None initiated Permission from IRB: Yes

\section{References}

1. WHO. Dengue and dengue haemorrhagic fever. Factsheet No 117, revised May 2008. Geneva, World Health Organization, 2008 (http: //www.who.int/ mediacentre/ factsheets/fs117/en/).

2. Monath TP. Dengue: the risk to developed and developing countries. Proc Natl Acad Sci U S A. 1994 Mar 29;91(7):2395-400.

3. Gubler DJ. Dengue and dengue hemorrhagic fever. Clin Microbiol Rev. 1998 Jul;11(3):480-96.

4. Leitmeyer KC, Vaughn DW, Watts DM, Salas R, Villalobos I, de Chacon, Ramos C, Rico-Hesse R. Dengue virus structural differences that correlate with pathogenesis. J Virol. 1999 Jun;73(6):4738-47.

5. Lanciotti RS, Lewis JG, Gubler DJ, Trent DW. Molecular evolution and epidemiology of dengue-3 viruses. J Gen Virol. 1994 Jan; 75 ( $\mathrm{Pt} 1$ ): $65-75$.

6. Messer WB, Gubler DJ, Harris E, Sivananthan K, de Silva AM. Emergence and global spread of a dengue serotype 3, subtype III virus. Emerging Infectious Diseases, 2003, 9(7):800--809. http://www.cdc.gov/ ncidod/ EID/vol9no7/03-0038.htm

7. Rodenhuis-Zybert IA, Wilschut J, Smit JM. Dengue virus life cycle: viral and host factors modulating infectivity. Cell Mol Life Sci. 2010 Aug; 67 (16): 277386. doi: 10.1007/s00018-010-0357-z. Epub 2010 Apr 6.

8. Normile D. Tropical medicine. Surprising new dengue virus throws a spanner in disease control efforts. Science. 2013 Oct 25;342(6157):415. doi: 10.1126/ science. 342. 6157.415.

9. Kaihatsu K, Harada E, Matsumura H, Takenaka A, Wichukchinda N, et al., (2016) Future Perspective of Nucleic Acid-based Detection of Dengue Virus and its Serotypes. J Antivir Antiretrovir 8:LXIX-LXXII. doi: 10. 4172/jaa.1000e132.

10. Magpusao NS, Monteclar A, Deen JL.Slow improvement of clinically diagnosed dengue haemorrhagic fever case fatality rates. Trop Doct, 200: 33 (3):156-159.
11. Magpusao NS, Monteclar A, Deen JL. Slow improvement of clinically-diagnosed dengue haemorrhagic fever case fatality rates. Trop Doct. 2003 Jul; 33 (3):156-9.

12. Badave GK, P. Sai Swaroop, P. Nageswara Rao. Importance of NS1 antigen detection and its association with platelet count for early diagnosis of dengue virus infection. Int. J. Curr. Microbiol. App. Sci 2015; 4(3): 779- 84 .

13. Kulkarni RD, Patil SS, Ajantha GS, Upadhya AK, Kalabhavi AS, Shubhada RM, Shetty PC, Jain PA. Association of platelet count and serological markers of dengue infection- importance of NS1 antigen. Indian J Med Microbiol. 2011 Oct-Dec;29(4):359-62. doi: 10. 4103/0255-0857.90159.

14. Datta S, Wattal C. Dengue NS1 antigen detection: a useful tool in early diagnosis of dengue virus infection. Indian J Med Microbiol. 2010 Apr-Jun;28(2):107-10. doi: 10.4103/0255-0857.62484.

15. Shrivastava A, Dash PK, Tripathi NK, Sahni AK, Gopalan N, Lakshamana. Evaluation of commercial dengue NS1 enzyme-linked immunosorbent assay for early diagnosis of dengue infection. Indian $\mathrm{J}$ Med Microbiol 2011;29:51-56.

16. Sindhanai V, Sageera B, Rajkumar N, Suresh C, Evaluation of Correlation between Dengue Serological Markers and Platelet Count. Sch. J. App. Med. Sci., 2016; 4(2D):618-622.

17. Philippe B, Sutee Y, Rosanna W; Peeling, Elizabeth $\mathrm{H}$; Laboratory Tests For The Diagnosis Of Dengue Virus Infection; Working paper for the Scientific Working Group on Dengue Research, convened by the Special Programme for Research and Training in Tropical Diseases, Geneva, 2006.

18. Golia S, Halli VH, Sujatha K, Karjigi, Reddy M, Kamath AS. Serodiagnosis of dengue using NS1 antigen, dengue IgM, dengue IgG antibody with correlation of platelet counts. International Journal of AJ Institute of Medical Sciences 2012; 1(2).112-117.

19. Ghosh K, Gangodkar S, Jain P, Shetty S, Ramjee S, Poddar P, Basu A. Imaging the interaction between dengue 2 virus and human blood platelets using atomic force and electron microscopy. $\mathrm{J}$ Electron Microsc (Tokyo). 2008 Jun;57(3):113-8. doi: 10.1093/jmicro/ dfn007. Epub 2008 May 8. 


\section{Original Research Article}

20. Basu A, Jain P, Gangodkar SV, Shetty S, Ghosh K. Dengue 2 virus inhibits in vitro megakaryocytic colony formation and induces apoptosis in thrombopoietininducible megakaryocytic differentiation from cord blood CD34+ cells. FEMS Immunol Med Microbiol. 2008 Jun;53(1):46-51. doi: 10.1111/j.1574-695X.2008. 00399.x. Epub 2008 Mar 25.
21. Rao SM. Correlation of clinical and laboratory parameters in dengue fever patients and its usefulness as bedside markers. Indian Journal of Critical Care Med. 2014; 18 (3):183-184. doi:10.4103/0972-5229. 128713.

\section{How to cite this article?}

Kambale T.J, Sawaimul K.D, Iqbal M.B, Bardapurkar P, Kumar H, Baravkar A. Correlation of serological markers with haematological parameters in early diagnosis of dengue infection in dengue prone areas. Trop J Path Micro 2018;4(1):7681. doi: 10.17511/jopm.2018.i1.14. 